\title{
Customer Loyalty: The Difference between Full-Service Carriers and Low-Cost Carriers in Indonesia
}

\author{
Yasintha Soelasih $^{1 *}$; Sumani ${ }^{2}$ \\ ${ }^{1-2}$ Faculty of Economics and Business, Atma Jaya Catholic University of Indonesia \\ Jln. Jend. Sudirman No.51, Jakarta Selatan 12930, Indonesia \\ 1yasintha.soelasih@atmajaya.ac.id; ${ }^{2}$ sumani@atmajaya.ac.id
}

Received: $8^{\text {th }}$ June 2020/ Revised: $9^{\text {th }}$ July 2020/ Accepted: $31^{\text {st }}$ August 2020

How to Cite: Soelasih, Y., \& Sumani. (2021). Customer Loyalty: The Difference between Full-Service Carriers and LowCost Carriers in Indonesia. Binus Business Review, 12(1), 21-29. https://doi.org/10.21512/bbr.v12i1.6489

\begin{abstract}
The level of competition in the aviation industry has increased since the regulation change in 1999. Aviation companies in providing services can be divided into three categories: full service, medium service, and no-frills service. Both Full-Service Carriers (FSCs) and Low-Cost Carriers (LCCs) experience a high level of competition. The research aimed to look at the differences in customer loyalty on domestic FSCs and LCCs in Indonesia. The differences were shown from testing the effect of service quality on customer loyalty mediated by customer satisfaction and behavioral intention to use. Respondents were FSCs and LCCs passengers. Samples were taken by purposive sampling. There were 522 respondents for FSCs and 529 respondents for LCCs were observed by distributing questionnaires. Then, the research tested the validity and reliability of the variables using Confirmatory Factor Analysis (CFA), Composite Reliability (CR), and Average Variance Extracted (AVE). Structural Equation Modeling (SEM) was also applied to examine the hypothesis. The results show the formation of customer loyalty from service quality, customer satisfaction, and behavioral intention to use on FSCs and LCCs. The most significant factor is the behavioral intention in forming customer loyalty in FSCs and LCCs. Meanwhile, customer satisfaction does not influence customer loyalty for FSCs and LCCs.
\end{abstract}

Keywords: customer loyalty, Full-Service Carriers, Low-Cost Carriers

\section{INTRODUCTION}

The level of competition in the aviation industry increased after regulation changed in 1999. In terms of services in the aviation industry, it can be divided into three categories: full service, medium service, and no-frills service (Kementerian Perhubungan Republik Indonesia, 2010). The research analyzes two categories, namely full service (Full-Service Carriers (FSCs)) and no-frills service (Low-Cost Carriers (LCCs)). Both experience a high level of competition.

Grönroos (1984) started the development of service quality in 1984 . The researcher tested the perceived service quality through an image formed from technical and functional quality. Then, Parasuraman, Zeithaml, and Berry (1985) developed a dimension in service quality. The basis of Grönroos' research was the basis for the development of service quality. Likewise, Park, Robertson, and Wu (2006) used the Parasuraman's service quality dimension with modifications in the airline. Next, An and Noh (2009) also developed the dimensions using the service quality dimension of Parasuraman Zeithaml Berry (PZB) through customized development on the research object.

The development in the dimensions of service quality leads to the emergence of dimensions that do not refer to the PZB dimensions. Ali, Dei, and Filieri (2015) agreed that customer satisfaction influenced by service quality dimensions, namely airline tangibles, terminal tangibles, personnel, empathy, and image. These dimensions differed from Parasuraman's dimensions: tangibles, empathy, responsiveness, reliability, and assurance. Qasim (2017) and EtemadSajadi, Way, and Bohrer (2016) mentioned that the adjustment of dimensions in the development of the studied object was due to customers' desire in a flight that began during pre-flight. Then, the dimensions 
formed customer satisfaction and customer loyalty.

Many previous researchers have discussed service quality, customer satisfaction, and customer loyalty on airlines. However, they have not added the effect of service quality on behavioral intention to use. Therefore, the research is developed by adding the variable of behavioral intention to use to see differences between FSCs and LCCs in Indonesia. Those are two concepts of airlines in Indonesia.

Service companies put more emphasis on service quality to build customer satisfaction. Service quality is the main thing that needs to be considered in shaping customer satisfaction. Jager and Jan (2016) explored service quality on a flight by conducting an exploratory factor analysis and confirmatory factor analysis. They produced two dimensions of service quality: non-flight related paid services and auxiliary airport services. Similarly, Soelasih (2015) used six dimensions in service quality on flights. Next, Byun, Lee, and Rye (2014) evaluated service quality between FSCs and LCCs using the KANO model. Meanwhile, Chotivanich (2014) investigated the effect of service quality on customer loyalty through customer satisfaction on domestic full-service airlines in Thailand. The development of service quality dimensions used by researchers in-flight objects are shown in Table 1. It shows the use of different dimensions of service quality for airline research. Service quality in the research refers to the dimensions of Soelasih (2015): flight information, tickets, checkin, on-time performance, in-flight, and post-flight.

Ali et al. (2015) and Jahmani (2017) showed that service quality shaped customer satisfaction. Similarly, Usha and Kusuma (2017) stated that competition between airlines was very high, so it is necessary to pay attention to service quality to create passengers' satisfaction. Thus, those dimensions were related. Then, Wongleedee (2017) measured the level of satisfaction between FSCs and LCCs. He produced different indicators in forming satisfaction. For LCCs, the indicators were price, the channel of purchasing, location, promotion, on-time performance, image, brand, safety, and service in flight, and finally, checkin. In contrast, FSCs indicators were brand, promotion, service in flight, image, check-in, safety, prices, the channel of purchasing, on-time performance, and location.

Another researcher, Qasim (2017), also showed that pre-flight service was essential in shaping customer satisfaction so that if there were problems in pre-flight, the company performed service recovery. Then, Kim (2015) suggested that customer satisfaction of LCCs did not influence purchase intentions. Meanwhile, for FSCs, there was an influence of customer satisfaction on purchase intentions.

Efthymiou, Njoya, Lo, Papatheodorou, and Randall (2019) stated that service quality delays caused low customer satisfaction, so that service recovery was needed. Hence, the on-time performance required to be improved by the company because it caused high customer satisfaction. Similarly, Farooq,
Salam, Fayolle, Jaafar, and Ayupp (2018) stated that the dimensions of airline tangibles, terminal tangibles, personnel services, empathy, and image influenced customer satisfaction. From the mentioned literature review, the first hypothesis in the research is as follows.

H1 : there is an effect of service quality on customer satisfaction on FSCs and LCCs

Next, Shah, Syed, Imam, and Raza (2020) showed that service quality influenced behavioral intention through customer satisfaction. Kim and Park (2016) also stated that an influence between service delay and on-time performance on the decrease in repurchase intention was a concern for airlines. However, Lerrthaitrakul and Panjakajornsak (2014) said that service quality on tangible and responsiveness did not affect behavioral intention. Meanwhile, reliability, assurance, and empathy influenced it. Park and Park (2016) stated that dissatisfied customers affected behavioral intention, so there was a need to make service recovery that caused customer satisfaction recovery.

Irtema, Ismail, Borhan, Das, and Alshetwi (2018) said that customer satisfaction influenced behavioral intention to use. Similarly, Suhud and Bajunaid (2018) agreed that service quality influences repurchase intention through customer satisfaction. Based on the previous research, the second and third hypotheses are:

H2 : There is an effect of service quality on behavioral intention to use on FSCs and LCCs

H3 : There is an effect of customer satisfaction on behavioral intention to use on FSCs and LCCs

Moreover, Chotivanich (2014) emphasized that loyalty was formed when satisfaction occurred. Hence, there was no direct effect between service quality to customer loyalty. Similarly, Park, Lee, Kwon, and Pobil (2015) showed that corporate social responsibility had a more substantial influence on behavioral intention to use through customer satisfaction than service quality.

Etemad-Sajadi et al. (2016) mentioned that preflight was more able to form customer satisfaction, causing customer loyalty than in-flight. However, Sandada and Matibiri (2016), Yang et al. (2017), Nurcahyo, Fitriani, and Hudda (2017) showed that service quality influenced customer loyalty through customer satisfaction. Paek and Lee (2018) stressed the need for staff education in service quality because it could increase customer satisfaction and customer loyalty. Soelasih (2017) also emphasized that customer satisfaction did not always form loyalty.

Chen and Liu (2017) showed that service quality had an influence on customer loyalty through higher perceived value than the direct effect of service quality on customer loyalty. Then, Rahim (2016) analyzed the service quality with dimensions of reliability, responsiveness, assurance, customization, employees, facilities, and flight patterns. Those 
dimensions influenced customer loyalty through customer satisfaction.

Meanwhile, Ahmad, Jun, Khan, Abdullah, and Ghauri (2016) and Chatterjee, Shainesh, and Sravanan (2018) said that customer loyalty influenced purchase intention. Similarly, Topcu and Duygun (2015) agreed that customer loyalty affected repurchase intention. Iqbal, Hassan, and Habibah (2018) conducted a study of the effect of customer satisfaction on customer loyalty and behavioral intention. They found a significant result, but they did not test the effect of behavioral intention on customer loyalty. However, Akroush and Mahadin (2019) showed that behavioral loyalty (behavioral intention) influenced cognitive loyalty. Based on the research of the relationship between customer satisfaction, behavioral intention to use, and customer loyalty, the fourth and fifth hypotheses are:

H4 : There is an effect of customer satisfaction on customer loyalty on FSCs and LCCs

H5 : There is an effect of behavioral intention to use on customer loyalty on FSCs and LCCs
The difference in the research compared to previous research is the variable of behavioral intention to use. Previous research focuses more on the effect of service quality on customer loyalty through customer satisfaction. However, there is the emergence of customer loyalty when customers use the same service and brand. The same uses continuously will lead to loyalty. Therefore, it is necessary to create behavioral intention to use to form loyalty apart from customer satisfaction. Another importance of forming behavioral intention to use, in addition to customer satisfaction for service companies, is to increase the number of customers.

The novelty in the research is to test behavioral intention to use as a mediating variable. The research examines the effect of service quality on customer loyalty mediated by customer satisfaction and behavioral intention to use on domestic FSCs and LCCs in Indonesia. The research results are expected to affect service quality on customer loyalty through customer satisfaction and behavioral intention to use on the concept of FSCs and LCCs in Indonesia. Therefore, the applied research model can be seen in Figure 1.

Table 1 Dimensions of Service Quality

\begin{tabular}{cll}
\hline No. & Research & Dimensions \\
\hline 1. & Byun et al. (2014) & Physical service, human service, system service \\
2. & Chotivanich (2014) & Perceivable positive feelings, mindfulness, trust and reliability \\
3. & Ali et al. (2015) & Airlines tangibles, terminal tangibles, personnel quality, empathy, airline image \\
4. & Hussain, Nasser, and Hussain (2015) & $\begin{array}{l}\text { Reliability, responsiveness, assurance, tangibility, security and safety, } \\
\text { communication }\end{array}$ \\
5 & Soelasih (2015) & Information, ticket, check-in, on-time performance, in-flight, post-flight \\
6. & Yang, Shih, Nha, and Wang (2017) & Assurance, responsiveness, tangibles, empathy \\
\hline
\end{tabular}

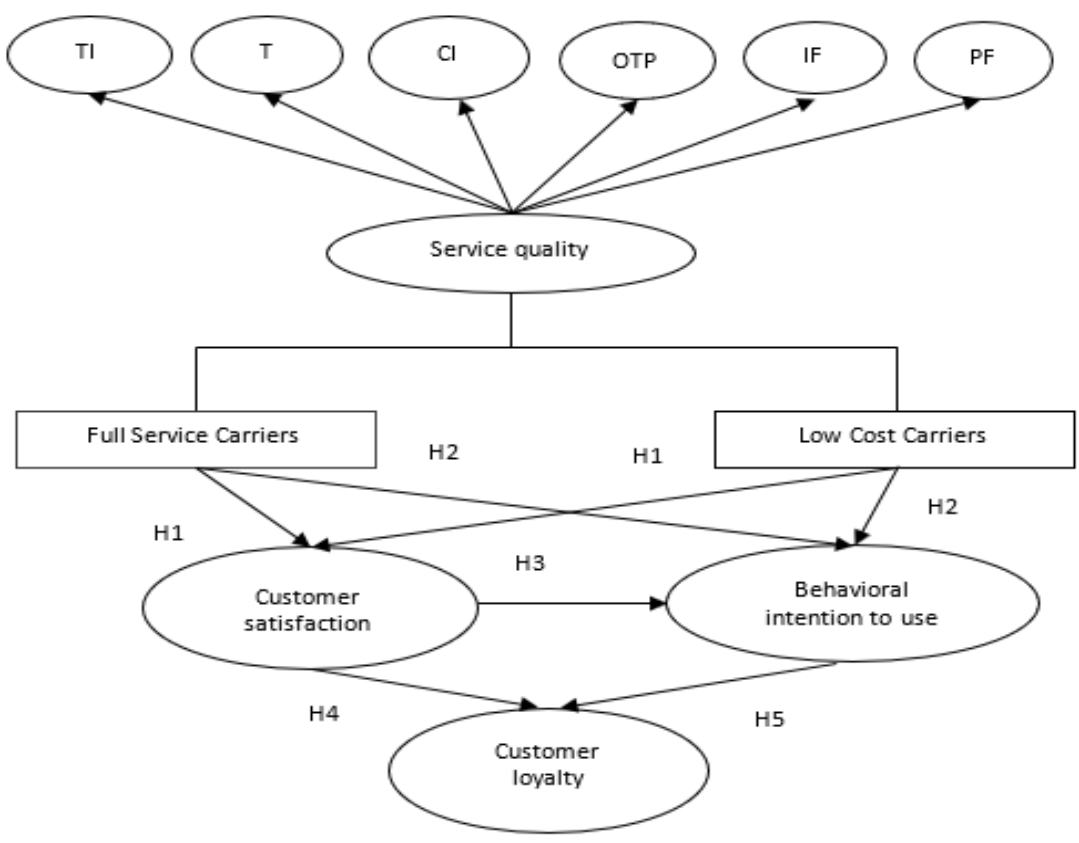

Figure 1 Research Model

Note: Ticket information (TI), ticketing (T), check-in (CI), on-time performance (OTP), in-flight (IF), and post-flight (PF) 


\section{METHODS}

The used instrument refers to previous research. For service quality, the research uses the dimensions from Soelasih (2015). Then, the instrument of customer satisfaction refers to Yang et al. (2017). Meanwhile, the used instruments of behavioral intention to use are from Park et al. (2015). For customer loyalty instruments, those refer to Chen and Liu (2017).

The used data scale is nominal and interval. Nominal data consist of gender, education, and job. Meanwhile, interval data are age, service quality, customer satisfaction, behavioral intention to use, and customer loyalty.

The research population is flight passengers of FSCs and LCCs. The sampling technique is purposive sampling with the criteria of being FSCs and LCCs passengers. Non-probability sampling can be used if there is a problem in the sample framework even though the aim is for theory generalization (Hulland, Baumgartner, \& Smith, 2018; Memon, Ting, Ramayah, Chuah, \& Cheah, 2017). Questionnaires were distributed online in January-March 2020. It is done as there is an increase in online data collection compared to letters (Hulland et al., 2018). The taken samples are 522 for FSCs and 529 for LCCs.

Next, the validity and reliability tests are performed on instruments and variables. The validity construct uses the Confirmatory Factor Analysis (CFA) (Memon et al., 2017). For reliability test, it is Composite Reliability (CR) and Average Variance Extracted (AVE). The measurement of reliability is all above the CR value of 0,6 , and AVE is above 0,05 (Fornell \& Larcker, 1981). Then, Structural Equation Modeling (SEM) is used to examine the hypothesis.

\section{RESULTS AND DISCUSSIONS}

Table 2 shows that most respondents for FSCs are male. Meanwhile, it is female for the LCCs. It shows that women tend to choose lower fares, so they use LCCs. The average age in the two groups is the same. Most of them are between the age of 18-25. For occupation, in LCCs, most of them are private employees, while FSCs are students. It shows that students do not consider costs too much because they are still dependent on their parents. Moreover, both FSCs and LCCs are mostly used for vacation.

The results of the validity and reliability tests in Table 3 (see Appendices) show that the value of all indicators and variables are above 0,5. It means that the used indicators can measure the variables in the research model. To test the used latent variables, SEM serves to confirm the theory (Memon et al., 2017). The results of testing the model with SEM are shown in Table 4 (see Appendices).

The model test results show that the model for FSCs and LCCs based on their values can be said to be fit. Table 4 (see Appendices) shows that the values of PGFI, NFI, RFI, IFI, CFI, and PNFI meet the requirements because they are above the recommended levels in the FSCs and LCCs models. Hence, the model can be used in the research. After the model fit, the hypotheses are analyzed using SEM with Lisrel 8.8. The results are in Table 5 (see Appendices).

In $\mathrm{H} 1$, the result shows that service quality affects customer satisfaction on FSCs and LCCs. H1 is accepted. The t-value is 15,21 for FSCs and 15,32 for LCCs. Those values are above the t-value of 1,96. It supports the research conducted by Ali et al. (2015), Jahmani (2017), Qasim (2017), and Farooq et al. (2018).

Table 2 The Respondents' Characteristics in the Research

\begin{tabular}{llll}
\hline Characteristic & & FSCs & LCCs \\
\hline Gender & Male & $274(52,5 \%)$ & $257(48,6 \%)$ \\
& Female & $248(47,5 \%)$ & $272(51,4 \%)$ \\
Age & $18-25$ & $307(58,8 \%)$ & $225(42,5 \%)$ \\
& $26-35$ & $104(20 \%)$ & $151(28,5 \%)$ \\
Occupation & $36-45$ & $43(8,2 \%)$ & $74(14 \%)$ \\
& $>45$ & $68(13 \%)$ & $79(15 \%)$ \\
& Undergraduate Student & $199(38,1 \%)$ & $56(10,6 \%)$ \\
& Entrepreneur & $79(15,1 \%)$ & $71(13,4 \%)$ \\
& Government Employee & $58(11,1 \%)$ & $141(26,7 \%)$ \\
& Private Employee & $127(24,4 \%)$ & $233(44 \%)$ \\
& Others & $59(11,3 \%)$ & $28(5,3 \%)$ \\
& Business & $69(13,2 \%)$ & $31(5,9 \%)$ \\
& Government Work & $9(1,7 \%)$ & $28(5,3 \%)$ \\
& Private Work & $25(4,8 \%)$ & $53(10 \%)$ \\
& Travel Tourism & $282(54 \%)$ & $309(58,4 \%)$ \\
& Family Visit & $137(26,3 \%)$ & $108(20,4 \%)$ \\
\hline
\end{tabular}


Airline companies with the concept of FSCs and LCCs need to pay attention to service quality to create customer satisfaction. If the service quality received is low, the customers will be dissatisfied.

In H2, there are two results. First, on FSCs, service quality does not influence behavioral intention to use. H2 in FSCs is rejected. Customers who use FSCs prioritize satisfaction. After being satisfied, they want to use it again. The result supports the research of Lerrthaitrakul and Panjakajornsak (2014). However, there is a relationship between service quality and behavior intention to use for LCCs with a t-value of 4,09 and coefficient value of 0,2 . Hence, H2 in LCCs is accepted, although the coefficient value is very weak between service quality and behavioral intention to use. It means that customers know that the operated flights are not based on service but other considerations, such as price (Wongleedee, 2017). Even though the service is minimal, customers continue to have behavioral intention to use on LCCs. Meanwhile, companies with the concept of FSCs can emphasize service quality, so that service quality will shape customer satisfaction and influence behavioral intention to use.

The result for $\mathrm{H} 3$ shows that customer satisfaction influences behavioral intention to use for FSCs and LCCs. Hence, H3 is accepted. The t-value is 15,97 for FSCs and 11,27 for LCCs. Companies need to create customer satisfaction because the formed satisfaction will affect the customers to reuse the same flight. If they use the same flight, the company can retain its customers not to decrease the level of flight usage. Therefore, for airlines, service quality needs to be improved. These results support the research of Park and Park (2016), Irtema et al. (2018), Suhud and Bajunaid (2018), and Shah et al. (2020).

In $\mathrm{H} 4$, the result suggests that customer satisfaction has no direct effect on customer loyalty. However, through behavioral intention to use, there is an effect on customer loyalty. The t-value is $-0,05$ for FSCs and 0,30 for LCCs. Those values are below the minimum $\mathrm{t}$-value of 1,96 . Therefore, $\mathrm{H} 4$ is rejected for FSCs and LCCs. The customers are not necessarily loyal to the same flight. They choose the flight according to their needs and wants. Hence, it causes them to be disloyal to the same flight. Companies still need to pay attention to service quality, affecting customer satisfaction and behavioral intention, even though it does not cause loyalty. Behavioral intention to use can maintain the company's market share. The results are in line with the research conducted by Soelasih (2017) in rail transportation. Nevertheless, the H4 results do not support the research of Chotivanich (2014), Etemad-Sajadi et al. (2016), Rahim (2016), and Nurcahyo et al. (2017).

The result for H5 shows that behavioral intention to use influences customer loyalty for FSCs and LCCs. The t-value is 12,82 for FSCs and 11,05 for LCCs. Behavioral intention to use is essential because if customers continuously use the same flight, it will lead to customer loyalty. It implies that H5 is accepted. It shows that behavioral intention to use needs to be improved by the company. The increased behavioral intention to use by enhancing service quality and customer satisfaction can develop customer loyalty. The result supports the research of Akroush and Mahadin (2019).

The research proves that behavioral intention to use can be used as a mediating variable. Many previous researchers have used behavioral intention to use as dependent or endogenous variables. The contribution shows the difference between the research and the previous one that the behavioral intention to use as a mediating variable affects customer loyalty through service quality and customer satisfaction.

The results can be used by airlines, especially those whousethe concept of FSCs toimprove behavioral intention to use through customer satisfaction formed by service quality. It means that service quality is the main priority for FSCs customers because the received service quality exceeds customers' expectations. Then, it will form satisfaction, behavioral intention to use, and loyalty. Meanwhile, LCCs companies also need to pay attention to service quality even with the concept of no-frills service. The results show that service quality forms customer loyalty mediated by customer satisfaction and behavioral intention to use. Nevertheless, there is a significant difference between service quality at FSCs and LCCs for customers. The difference in services has implications for the imposed costs on the two types of airlines.

\section{CONCLUSIONS}

The research aims to analyze the differences in customer loyalty on domestic FSCs and LCCs in Indonesia. It tests the effect of service quality on customer loyalty mediated by customer satisfaction and behavioral intention to use. From the test, in forming customer loyalty in FSCs and LCCs, it is affected by behavioral intention to use, not customer satisfaction. The level of customer loyalty on FSCs flights is higher than LCCs. It means that the customers who use FSCs are more loyal than LCCs. Customer loyalty is shown by high behavioral intention to use. It is due to customer satisfaction from service quality received by FSCs customers.

The limitation of the research is that the researchers do not examine the tariff variable. The tariff is a sacrifice made by customers to obtain the services. Customer satisfaction is a comparison between performance and expectations. Nevertheless, customers expect the sacrifices to balance the received performance of the airlines. A correlation between service quality and the tariff will form customers' perceptions that affect satisfaction and behavioral intention to use. Hence, future research can add the tariff variable.

\section{ACKNOWLEDGEMENTS}

The research was supported by a grant from the Ministry of Research and Technology, the Republic 
of Indonesia, in 2020. The authors are also indebted to the Ministry of Research and Technology and the Faculty of Economics and Business at Atma Jaya Catholic University of Indonesia for assisting in the research.

\section{REFERENCES}

Ahmad, Z., Jun, M., Khan, I., Abdullah, M., \& Ghauri, T. A. (2016). Examining mediating role of customer loyalty for influence of brand related attributes on customer repurchase intention. Journal of Northeast Agricultural University (English Edition), 23(2), 8996. https://doi.org/10.1016/S1006-8104(16)30052-6

Akroush, M. N., \& Mahadin, B. K. (2019). An intervariable approach to customer satisfaction and loyalty in the internet service market. Internet Research, 29(4), 772-798. https://doi.org/10.1108/IntR-12-20170514

Ali, F., Dei, B. L., \& Filieri, R. (2015). An assessment of service quality and resulting customer satisfaction in Pakistan International Airlines: Findings from foreigners and overseas Pakistani customers. International Journal of Quality \& Reliability Management, 32(5), 486-502. https://doi. org/10.1108/IJQRM-07-2013-0110

An, M., \& Noh, Y. (2009). Airline customer satisfaction and loyalty: Impact of in-flight service quality. Service Business, 3, 293-307. https://doi.org/10.1007/ s11628-009-0068-4

Byun, H., Lee, B., \& Rye, J. (2014). A comparative study on evaluating the service quality attributes based on Kano model: A case of low-cost carrier and fullservice carrier. SHS Web of Conferences, 12, 1-8. https://doi.org/10.1051/shsconf/20141201017

Chatterjee, S., Shainesh, G., \& Sravanan, C. N. S. (2018). Does intention translate into action? Investigating the impact of loyalty intention on future usage. Journal of Indian Business Research, 10(2), 151-169. https:// doi.org/10.1108/JIBR-11-2017-0213

Chen, C. M., \& Liu, H. M. (2017). Exploring the impact of airlines service quality on customer loyalty: Evidence from Taiwan. International Journal of Business and Management, 12(5), 36-50. https://doi. org/10.5539/ijbm.v12n5p36

Chotivanich, P. (2014). Service quality, satifaction, and customer loyalty in a full-service domestic airline in Thailand. International Journal of Arts \& Sciences, 7(3), 161-169.

Efthymiou, M., Njoya, E. T., Lo, P. L., Papatheodorou, A., \& Randall, D. (2019). The impact of delays on customers' satisfaction: An empirical analysis of the British Airways on-time performance at Heathrow Airport. Journal of Aerospace Technology and Management, 11, 1-13. https://doi.org/10.5028/jatm. v11.977

Etemad-Sajadi, R., Way, S. A., \& Bohrer, L. (2016). Airline passenger loyalty: The distinct effects of airline passenger perceived pre-flight and in-flight service quality. Cornell Hospitality Quarterly, 57(2), 219-
225. https://doi.org/10.1177/1938965516630622

Farooq, M. S., Salam, M., Fayolle, A., Jaafar, N., \& Ayupp, K. (2018). Impact of service quality on customer satisfaction in Malaysia airlines: A PLS-SEM approach. Journal of Air Transport Management, 67(March), 169-180. https://doi.org/10.1016/j. jairtraman.2017.12.008

Fornell, C., \& Larcker, D. (1981). Evaluating structural equation models with unobservable variables and measurement error. Journal of Marketing Research, 18(1), 39-50. https://doi.org/10.2307/3151312

Grönroos, C. (1984). A service quality model and its marketing implications. European Journal of Marketing, 18(4), 36-44. https://doi.org/10.1108/ EUM0000000004784

Hulland, J., Baumgartner, H., \& Smith, K. M. (2018). Marketing survey research best practices: Evidence and recommendations from a review of JAMS articles. Journal of the Academy of Marketing Science, 46, 92-108. https://doi.org/10.1007/s11747017-0532-y

Hussain, R., Nasser, A. A., \& Hussain, Y. K. (2015). Service quality and customer satisfaction of a UAE-based airline: An empirical investigation. Journal of Air Transport Management, 42(January), 167-175. https://doi.org/10.1016/j.jairtraman.2014.10.001

Iqbal, M. S., Hassan, M. U., \& Habibah, U. (2018). Impact of Self-Service Technology (SST) service quality on customer loyalty and behavioral intention: The mediating role of customer satisfaction. Cogent Business \& Management, 5(1), 1-23. https://doi.org/ 10.1080/23311975.2018.1423770

Irtema, H. I. M., Ismail, A., Borhan, M. N., Das, A. M., \& Alshetwi, A. B. Z. (2018). Case study of the behavioural intentions of public transportation passengers in Kuala Lumpur. Case Studies on Transport Policy, 6(4), 462-474. https://doi. org/10.1016/j.cstp.2018.05.007

Jager, J. W. D., \& Jan, M. T. (2016). Pre-flight expectations in the air transportation industry of South Africa: A confirmatory factor. Actual Problems of Economics, (186), 370-377.

Jahmani, A. (2017). The effect of Royal Jordanian Airline service quality on passengers' satisfaction. International Journal of Business and Society, 18(S3), 519-530.

Kementerian Perhubungan Republik Indonesia. (2010). Peraturan Menteri Perhubungan Nomor KM 26 tahun 2010. Retrieved from http://jdih. dephub.go.id/index.php/produk_hukum/view/ UzAwZ01qWWdWRUZJVIU0Z01qQXhNQT09

Kim, N. Y., \& Park, J. W. (2016). A study on the impact of airline service delays on emotional reactions and customer behavior. Journal of Air Transport Management, 57(October), 19-25. https://doi. org/10.1016/j.jairtraman.2016.07.005

Kim, Y. (2015). Assessing the effects of perceived value (utilitarian and hedonic) in LCCs and FSCs: Evidence from South Korea. Journal of Air Transport Management, 49(October), 17-22. https:// doi.org/10.1016/j.jairtraman.2015.07.001 
Lerrthaitrakul, W., \& Panjakajornsak, V. (2014). The airline service quality affecting post purchase behavioral intention: Empirical evidence from the low cost airline industry. International Journal of Trade, Economics and Finance, 5(2), 155-158. https://doi. org/10.7763/IJTEF.2014.V5.360

Memon, M. A., Ting, H., Ramayah, T., Chuah, F., \& Cheah, J. H. (2017). A review of the methodological misconceptions and guidelines related to the application of structural equation modeling: A Malaysian scenario. Journal of Applied Structural Equation Modeling, 1(1), 1-13.

Nurcahyo, R., Fitriani, A., \& Hudda, I. N. (2017). The influence of facility and service quality towards customer satisfaction and its impact on customer loyalty in Borobudur Hotel in Jakarta. Binus Business Review, 8(1), 23-29. https://doi.org/10.21512/bbr. v8i1.1790

Paek, J., \& Lee, C. W. (2018). The effect of education and training on service quality, customer satisfaction and loyalty in airline industry. Management Review: An International Journal, 13(1), 49-64.

Parasuraman, A., Zeithaml, V. A., \& Berry, L. L. (1985). A conceptual model of service quality and its implications for future research. Journal of Marketing, 49(4), 41-50. https://doi. org/10.1177/002224298504900403

Park, E., Lee, S., Kwon, S. J., \& Pobil, A. P. D. (2015). Determinants of behavioral intention to use South Korean Airline services: Effects of service quality and corporate social responsibility. Sustainability, 7(9), 12106-12121. https://doi.org/10.3390/ su70912106

Park, J. J., \& Park, J. W. (2016). Investigating the effects of service recovery quality elements on passengers' behavioral intention. Journal of Air Transport Management, 53(June), 235-241. https://doi. org/10.1016/j.jairtraman.2016.03.003

Park, J. W., Robertson, R., \& Wu, C. L. (2006). Modelling the impact of airline service quality and marketing variables on passengers' future behavioural intentions. Transportation Planning and Technology, 29(5), 359-381. https://doi. org/10.1080/03081060600917686

Qasim, S. (2017). Pre-flight service expectations of domestic airline passengers in Pakistan. Pakistan Business Review, 19(2), 394-410.
Rahim, A. G. (2016). Perceived service quality and customer loyalty: The mediating effect of passenger satisfaction in the Nigerian airline industry. International Journal of Management and Economics, 52(1), 94117. https://doi.org/10.1515/ijme-2016-0029

Sandada, M., \& Matibiri, B. (2016). An investigation into the impact of service quality, frequent flier programs and safety perception on satisfaction and customer loyalty in the airline industry in Southern Africa. South East European Journal of Economics and Business, 11(1), 41-53. https://doi.org/10.1515/jeb2016-0006

Shah, F. T., Syed, Z., Imam, A., \& Raza, A. (2020). The impact of airline service quality on passengers' behavioral intentions using passenger satisfaction as a mediator. Journal of Air Transport Management, 85(June). https://doi.org/10.1016/j.jairtraman.2020.101815

Soelasih, Y. (2017). Kepuasan konsumen tidak selalu membentuk loyalitas. Jurnal Manajemen, 21(3), 363-380. http://dx.doi.org/10.24912/jm.v21i3.257

Soelasih, Y. (2015). Is physical evidence still valid? A study of low cost carriers in Indonesia. Gadjah Mada International Journal of Business, 17(3), 203-218. https://doi.org/10.22146/gamaijb.8499

Suhud, U., \& Bajunaid, S. M. (2018). Satisfied, but will they spread a word? The role of customer satisfaction at Jamu Café. Binus Business Review, 9(1), 1-8. https:// doi.org/10.21512/bbr.v9i1.3915

Topcu, B., \& Duygun, A. (2015). The impacts of customer loyalty on negative word-of-mouth communication and repurchase intention. Journal of Marketing and Management, 6(1), 16-27.

Usha, P., \& Kusuma, E. (2017). A study on survive quality and passenger satisfaction on Air India services. International Journal of Advance Research, Ideas and Innovations in Technology, 3(4), 534-546.

Wongleedee, K. (2017). Customer satisfaction in the airlines industry: Comparison between low-cost and full service airlines. Актуальні Проблеми Економіки, (187), 218-222.

Yang, F. J., Shih, K. H., Nha, D. T., \& Wang, Y. H. (2017). Low-fare airlines service quality, customer satisfaction and customer loyalty. Journal of Accounting, Finance \& Management Strategy, 12(2), 97-122. 
Table 3 The Results of Validity and Reliability Tests

\begin{tabular}{|c|c|c|c|c|c|c|}
\hline \multirow{2}{*}{$\begin{array}{l}\text { Indicators/ } \\
\text { variable }\end{array}$} & \multicolumn{3}{|c|}{ FSCs } & \multicolumn{3}{|c|}{ LCCs } \\
\hline & CFA & CR & AVE & CFA & CR & AVE \\
\hline TI & & 0,87 & 0,58 & & 0,87 & 0,57 \\
\hline TI1 & 0,78 & & & 0,74 & & \\
\hline TI2 & 0,83 & & & 0,79 & & \\
\hline TI3 & 0,80 & & & 0,82 & & \\
\hline TI4 & 0,83 & & & 0,84 & & \\
\hline TI5 & 0,53 & & & 0,55 & & \\
\hline $\mathrm{T}$ & & 0,90 & 0,54 & & 0,88 & 0,50 \\
\hline $\mathrm{T} 1$ & 0,68 & & & 0,73 & & \\
\hline $\mathrm{T} 2$ & 0,77 & & & 0,72 & & \\
\hline $\mathrm{T} 3$ & 0,75 & & & 0,61 & & \\
\hline $\mathrm{T} 4$ & 0,62 & & & 0,63 & & \\
\hline T5 & 0,62 & & & 0,70 & & \\
\hline T6 & 0,80 & & & 0,75 & & \\
\hline $\mathrm{T} 7$ & 0,77 & & & 0,73 & & \\
\hline $\mathrm{T} 8$ & 0,82 & & & 0,72 & & \\
\hline CI & & 0.90 & 0.60 & & 0.87 & 0.52 \\
\hline CI1 & 0,74 & & & 0,65 & & \\
\hline CI2 & 0,73 & & & 0,72 & & \\
\hline $\mathrm{CI} 3$ & 0,82 & & & 0,75 & & \\
\hline CI4 & 0,81 & & & 0,72 & & \\
\hline CI5 & 0,76 & & & 0,74 & & \\
\hline CI6 & 0,78 & & & 0,74 & & \\
\hline OTP & & 0,83 & 0,63 & & 0,86 & 0,67 \\
\hline OTP1 & 0,77 & & & 0,84 & & \\
\hline OTP2 & 0,86 & & & 0,89 & & \\
\hline OTP3 & 0,74 & & & 0,71 & & \\
\hline IF & & 0,87 & 0,53 & & 0,86 & 0,51 \\
\hline IF1 & 0,53 & & & 0,78 & & \\
\hline IF2 & 0,55 & & & 0,81 & & \\
\hline IF3 & 0,82 & & & 0,77 & & \\
\hline IF4 & 0,83 & & & 0,74 & & \\
\hline IF5 & 0,80 & & & 0,59 & & \\
\hline IF6 & 0,76 & & & 0,58 & & \\
\hline $\mathrm{PF}$ & & 0,91 & 0,63 & & 0,88 & 0,56 \\
\hline PF1 & 0,68 & & & 0,76 & & \\
\hline PF2 & 0,69 & & & 0,77 & & \\
\hline PF3 & 0,77 & & & 0,68 & & \\
\hline PF4 & 0,78 & & & 0,76 & & \\
\hline PF5 & 0,90 & & & 0,77 & & \\
\hline PF6 & 0,90 & & & 0,74 & & \\
\hline $\mathrm{CS}$ & & 0,96 & 0,72 & & 0,94 & 0,63 \\
\hline CS1 & 0,82 & & & 0,74 & & \\
\hline $\mathrm{CS} 2$ & 0,81 & & & 0,76 & & \\
\hline $\mathrm{CS} 3$ & 0,82 & & & 0,84 & & \\
\hline CS4 & 0,83 & & & 0,81 & & \\
\hline
\end{tabular}


Table 3 The Results of Validity and Reliability Tests (Continued)

\begin{tabular}{|c|c|c|c|c|c|c|}
\hline \multirow{2}{*}{$\begin{array}{l}\text { Indicators/ } \\
\text { variable }\end{array}$} & \multicolumn{3}{|c|}{ FSCs } & \multicolumn{3}{|c|}{$\mathrm{LCCs}$} \\
\hline & CFA & CR & AVE & CFA & CR & AVE \\
\hline CS5 & 0,86 & & & 0,80 & & \\
\hline CS6 & 0,82 & & & 0,71 & & \\
\hline CS7 & 0,88 & & & 0,81 & & \\
\hline CS8 & 0,89 & & & 0,83 & & \\
\hline $\mathrm{CS} 9$ & 0,89 & & & 0,81 & & \\
\hline BI & & 0,92 & 0,74 & & 0,90 & 0,68 \\
\hline BI1 & 0,82 & & & 0,80 & & \\
\hline BI2 & 0,86 & & & 0,84 & & \\
\hline BI3 & 0,87 & & & 0,85 & & \\
\hline BI4 & 0,89 & & & 0,81 & & \\
\hline $\mathrm{CL}$ & & 0,88 & 0,72 & & 0,85 & 0,65 \\
\hline CL1 & 0,88 & & & 0,83 & & \\
\hline CL2 & 0,81 & & & 0,75 & & \\
\hline CL3 & 0,85 & & & 0,83 & & \\
\hline
\end{tabular}

Notes: Ticket information (TI), ticketing (T), check-in (CI), on-time performance (OTP), in-flight (IF), post-flight (PF), customer satisfaction (CS), behavioral intention to use (BI), customer loyalty (CL), Confirmatory Factor Analysis (CFA), Composite Reliability (CR), and Average Variance Extracted (AVE)

Table 4 Fit Indicators of the Measurement Model

\begin{tabular}{lccc}
\hline Fit indicators & Recommended level & $\begin{array}{c}\text { Measurement } \\
\text { model of FSCs }\end{array}$ & $\begin{array}{c}\text { Measurement } \\
\text { model of LCCs }\end{array}$ \\
\hline Chi-square/d.f & $<5,000$ & 5,990 & 4,460 \\
Goodness of Fit Index (GFI) & $>0,800$ & 0,650 & 0,720 \\
Parsimony Goodness of Fit Index (PGFI) & $>0,500$ & 0,590 & 0,650 \\
Normed Fit Index (NFI) & $>0,800$ & 0,960 & 0,970 \\
Relative Fit Index (RFI) & $>0,800$ & 0,960 & 0,960 \\
Incremental Fit Index (IFI) & $>0,900$ & 0,970 & 0,980 \\
Comparative Fit Index (CFI) & $>0,900$ & 0,970 & 0,980 \\
Parsimony Normed Fit Index (PNFI) & $>0,500$ & 0,910 & 0,920 \\
Root Mean Square Error of Approximation (RMSEA) & $<0,080$ & 0,098 & 0,081 \\
\hline
\end{tabular}

(Source: Park et al., 2015)

Table 5 Hypothesis Test Results

\begin{tabular}{|c|c|c|c|c|c|c|c|}
\hline & \multirow[b]{2}{*}{ Hypotheses } & \multicolumn{3}{|c|}{ FSCs } & \multicolumn{3}{|c|}{ LCCs } \\
\hline & & $\begin{array}{l}\text { Standardized } \\
\text { coefficient }\end{array}$ & t-value & Results & $\begin{array}{c}\text { Standardizes } \\
\text { coefficients }\end{array}$ & T-value & Results \\
\hline H1 & $\begin{array}{l}\text { Service quality toward customer } \\
\text { satisfaction }\end{array}$ & 0,69 & 15,21 & Supported & 0,75 & 15,32 & Supported \\
\hline $\mathrm{H} 2$ & $\begin{array}{l}\text { Service quality toward behavioral } \\
\text { intention to use }\end{array}$ & 0,07 & 1,78 & Rejected & 0,20 & 4,09 & Supported \\
\hline H3 & $\begin{array}{l}\text { Customer satisfaction toward } \\
\text { behavioral intention to use }\end{array}$ & 0,82 & 15,97 & Supported & 0,67 & 11,27 & Supported \\
\hline $\mathrm{H} 4$ & $\begin{array}{l}\text { Customer satisfaction toward } \\
\text { customer loyalty }\end{array}$ & 0,00 & $-0,05$ & Rejected & 0,02 & 0,30 & Rejected \\
\hline H5 & $\begin{array}{l}\text { Behavioral intention to use toward } \\
\text { customer loyalty }\end{array}$ & 0,93 & 12,82 & Supported & 0,85 & 11,05 & Supported \\
\hline
\end{tabular}

